\title{
OVOP Approach (One Village One Product) in Managing Social Poverty
}

\author{
*Endang Murti Harianto Agus Wiyaka Nunik Hariyani \\ Faculty of Social and Political Sciences, Universitas Merdeka Madiun
}

\begin{abstract}
Social poverty is a classic problem and continues to be a crucial issue that the government must immediately resolve, because it involves the welfare of the lower class. A development strategy that is oriented towards economic growth and productivity has resulted in social inequality and injustice, therefore a development strategy by prioritizing community empowerment, especially rural communities, is expected to increase family income and welfare. The one village one product (OVOP) approach can be an alternative strategy for community economic empowerment because the target of development is the superior product of the village where most of the villagers are engaged in these business activities. Superior village products have specificities and are the development of the local cultural potential of each village, so that they have greater opportunities and access to compete competitively at the local, regional, national, and even international levels. The OVOP approach through fostering more modern business management can encourage a wider network so as to increase business productivity and community welfare.
\end{abstract}

Keywords: OVOP, empowerment, poverty, welfare

DOI: $10.7176 /$ RHSS/11-18-01

Publication date:September $30^{\text {th }} 2021$

\section{Background}

Social poverty is still a crucial issue that must be faced by the government because it involves the welfare and prosperity of the lower class. The growth paradigm, which is oriented towards economic growth through increased productivity, can only be enjoyed by a certain small group of elites, while the lower class of society does not benefit from the expected trickle-down effect. With this failure, encouraging the development paradigm by emphasizing equitable development and its results through the direction of sectoral development policies and community empowerment (people empowering), especially in rural areas, considering that the problem of poverty is mostly in rural areas.

In terms of context, the problem of social poverty is very complex and involves various aspects that influence it, be it economic, political, social, legal or cultural aspects. Poverty can be interpreted as a condition for someone who is unable to meet their daily needs, which is due to their low income level. Limited availability of natural resources affects the mobility of community businesses to be able to generate more income. However, there are also areas that have enough potential for better natural resources but the condition of the people is poor due to the limited ability of their human resources to utilize the potential of available natural resources. According to Ginandjar Kartasamita (1996: 234- 235), poverty is often characterized by high levels of unemployment and underdevelopment. The poor are generally weak in the ability to do business and have limited access to economic activities so that they will be left far behind from other communities with higher potential. According to Gunawan (1998) the factors that cause poverty can be grouped into two, namely: First, poverty that occurs is caused by external factors or factors beyond the reach of individuals. The condition of the people who are called poor can be identified based on their income ability to meet the standard of living. Second, in principle, the standard of living in a society is not only sufficient for food, but also for health and education needs. Furthermore, in the explanation of Wijayanti (2005), that: poverty can be seen from the primary and secondary aspects. The primary aspects are asset poor, socio-political organization, and low knowledge and skills. Meanwhile, the secondary aspects are poor in social networks, financial resources and information. On the other hand, poverty is also said to be a complex problem because it is not only related to the problem of low levels of income and consumption, but also to the low level of education, health and powerlessness to participate in development as well as various problems related to human development. The dimensions of poverty are manifested in the form of lack of nutrition, water, healthy housing, suboptimal health care, and low levels of education.

The condition of poverty in the village occurs because of low capacity which results in limited business activities carried out, with low ideas and creative ideas in utilizing potential economic resources in the environment. These ideas and ideas are a source of inspiration for economic activities that have the potential to grow economic mobility and increase people's income. Therefore, business capital, which is often assessed as the main factor of social poverty, is not correct, because ownership of business capital without being followed by creativity in exploiting existing opportunities will create limitations in economic activities. For this reason, village development must be focused on community empowerment, especially the development of existing 
economic potential, such as the development of people's businesses through strengthening the capacity of village institutions, as well as mastery of technology and utilization of natural resources. According to A. Gany (2001: 5), "The bottom-up village development fund policy is essentially nothing but a political developmentalism effort in the village, the implementation of which is emphasized on two aspects: first, creating space or opportunities for people to develop themselves. ; second, seeking community empowerment so that they are able to take advantage of the created space/opportunities". However, there was a democracy crisis, a condition in which the decision- making process (policy) concerning the people's livelihood, proceeded without substantial involvement. Restricting village people's access to the arena of policy making (political decision), policy makers position themselves as if they have the autonomy to make decisions, even without political participation and approval from the village people. Policies in the village are more of conventions that are built incrementally or in the form of expressions of thought by the apparatus that are spontaneously and a little impulsively applied as the direction of the village's pace of movement. The mobilization of community participation is weak, there is only participation in implementing mutual cooperation activities, community finances for activities related to village government services. Pluralistic participation is limited, people's participation is more focused on implementing development programs designed by the ruling elite. The implementation of the village development program by the government has made the village and its inhabitants increasingly powerless. The process of village development that is running does not make the village change, develop better and more meaningful, but on the contrary, this makes the village both social, economic and political, in fact it remains in poverty and underdevelopment. Development that is intended to give the people more choices about the desired future, however, the determined rural development program does not create hopes or possibilities for village public choice. Furthermore, Kartasasmita (1997:35), explains that: many empirical studies show the failure of development or development does not meet the targets due to lack of community participation, in fact many cases show people are against development efforts. This situation can occur due to several things: (1). Development only benefits a small group of people and does not benefit the people at large, even on the extreme side it is felt to be detrimental. (2). Development even though it is intended to benefit the people at large, but the people do not understand the purpose. (3)Development is intended to benefit the people and the people understand it, but the way it is implemented is not in accordance with that understanding. (4).Development is understood to benefit the people but the people are not included. From the weaknesses and failures of village development, the village government must have sensitivity in absorbing the aspirations and needs of the community, so that the resulting village development program is truly in accordance with the wishes of the residents. Community involvement is very important in the village development process, starting from problem identification, program design preparation, implementation, and utilization of development results. Community involvement is very much needed to bring the orientation of development programs closer to the interests of the community, so that the development programs that are set are truly a solution to overcome social problems faced by the community and at the same time grow the community to be responsible for the implementation of development.

Based on Law no. 06/2014 on Villages, it is explained that: Villages have the authority to regulate and manage their own households, including in formulating development programs according to the needs of villagers. According to Syahza and Suarman (2013) in A.D Murdani (2018), the ideal rural development must be able to follow four major efforts, in the form of a main rural development strategy. These four main strategies must be interrelated and sustainable, and the four main strategies for rural development are: (1) Empowering the economy of rural communities. To make it happen, capital and guidance are needed in the context of utilizing technology and marketing in order to enable and empower rural communities; (2). Improving the quality of rural human resources. The quality of human resources aims so that they have an adequate basis in order to increase and strengthen productivity and competitiveness; (3) Development of infrastructure in rural areas. Transportation infrastructure in rural areas is an absolute necessity, because this transportation infrastructure can spur the backwardness of rural communities; and (4) Developing rural institutions, both formal and non-formal. With this institution, good services can be created to spur the rural economy such as financial institutions. Meanwhile, the profile of rural business activities is relatively simple home-based activities and usually as a business from generation to generation, so there is still limited encouragement to increase the mobility of its business activities. In the case of rural business activities have special characteristics oriented to the development of existing cultural potentials. For this reason, village development should focus on developing community business activities through a more modern business management development strategy in order to have broader capabilities in increasing their productivity. One of the alternative rural economic development strategies is through the OVOP (one village one product) approach, which is currently in great demand and is being implemented in various developing countries in an effort to improve the welfare of villagers.

The One Village One Product movement is a form of concern over the socio-economic disparities of villagers, which causes most villagers to urbanize to the city to try their luck in order to improve their lives. The OVOP approach is an effort to empower villagers through developing and increasing the added value of local 
superior products, so as to improve the welfare of local communities. In implementing the development of one village with one product, it is hoped that each village will explore the potential of a superior product that is possible to become an icon in rural areas, through quality improvement and more modern product packaging can fill the potential of modern markets such as supermarkets, or even reach local markets., regional, national and even international. In the process of implementing OVOP, it begins with selecting community business products that are possible to be developed into superior village products that have certain characteristics that are not found in other areas. The products chosen for the OVOP movement are not only in the form of tangible products, but also in the form of intangible products, for example cultural and art products typical of regions that have high global selling value. According to Husaini (2011) suggests that OVOP in the form of the SAKA SAKTI concept (One Regency/City One Core Competence) is a concept developed in order to build the competitiveness of a region by creating core competencies for the region in order to compete at the global level. This concept is indispensable so that the resources and capabilities possessed by the regions are directed to create core competencies. There are two concepts in building core competencies through the OVOP movement approach. First, the concept of building superior products, namely developing local products that have advantages in terms of uniqueness, uniqueness, greater benefits for product users and provide great benefits for the producers of these products. Second, the concept of building regional core competencies, in this case the region must choose the core competencies of the region concerned in terms of uniqueness, regional uniqueness, natural resource wealth, opportunities to penetrate international markets and their impact (https://koperasi.kulonprogokab.go.id/ detail/147/ovop-indonesia). Thus, the OVOP approach can be revitalized into superior village products as an icon of village products that have high competitiveness and can reach wider marketing, so as to increase the productivity and welfare of rural communities.

\section{Literature review}

Poverty can be understood through various dimensions, many social aspects that affect the occurrence of poverty, such as low community income, powerlessness, unemployment, low working capital, and so on. Poverty, in general, is defined as the inability to meet basic needs, due to low income as a result of an individual's failure to obtain adequate employment opportunities. The World Bank in its publication, World Development Report 2000/2001: Attacking Poverty, defines poverty as a condition where a decent standard of living is not achieved. Furthermore, the World Bank uses inadequate clothing, food and shelter; inability to access health care; and low access to education, as an indicator to mark someone categorized as poor or not. Meanwhile, the United Nations (UN) in its publication, The World Situation Report 1997, described poverty as a condition related to the inability to meet basic needs. Like the World Bank, the UN also proposes several technical indicators that can be used as a marker of whether a person is poor or not, such as malnutrition, illiteracy, poor health, inadequate clothing and housing, and helplessness (http: //www.tnp2k.go .id / download / 79169WP480304FINAL.pdf). It is not much different from the formula of Bappenas (2004), that: poverty is a condition in which a person or group of people, men and women, is unable to fulfill their basic rights to maintain and develop a dignified life. These basic rights include, among others, the fulfillment of the needs for food, health, education, employment, housing, clean water, land, natural resources and the environment, a sense of security from treatment or threats of violence and the right to participate in socio-political life. To realize the basic rights of a person or group of poor people, Bappenas uses several main approaches, including; basic needs approach, income approach, human capability approach and objective and subjective approaches (http://www.braindilogsociology.or.id/2017/12/strategi-penanggulangan- poverty-in.html). Thus poverty can be seen from two aspects, namely: first, poverty shows a condition of a person who is in a state of complete deprivation in fulfilling his life needs. Second, poverty is defined as the inability of individuals or families to utilize existing resources to support their business activities.

According to Nugroho (1995), poverty is a condition of economic inability to meet living standards, especially the standards of public health needs and education standards, as a result the ability to achieve welfare standards is low, such as: (1) Food availability is not appropriate or does not meet the required nutritional standards. so that the risk of experiencing malnutrition or low nutritional conditions which in turn is very vulnerable to the risk of infectious diseases. (2) Health is relatively less secure so it is vulnerable to disease attacks and the ability to cover disease is also relatively limited so it is very vulnerable to the risk of death. (3) Housing or settlement that is less / unfit for habitation as a result of limited income to own / obtain land for shelter or to obtain an adequate place to live. This condition will have an impact on health. (4) Low level of education. This condition is caused by limited income to get the desired education or in accordance with educational standards. Furthermore, Nugroho (1995) explains that: the conditions due to the limitations or low income above cause the formation of a public health status that is said to be low (morbidity) or in a low nutritional condition. This condition is very susceptible to disease and malnutrition, which is accompanied by a high mortality rate. High mortality rates and low public health conditions will result in low social participation, higher absenteeism, low intelligence, and relatively low skills. It is further described as follows: (1) Low Social 
Participation Level. Low health and nutritional conditions lead to low physical resilience or physical capital required for social participation. This is because disturbed health cannot support full participation in both the community and work environment. Most of the poor are relatively rarely actively involved in social activities. (2) Attendance Increases. Factors of low health quality do not support the presence of aspects of community activities both in the social environment, education, and work. As a result, absenteeism or absenteeism in all activities is increasing so that they do not have the opportunity to play an active role in the social environment. (3) Low Intelligence. Factors of poor nutrition or low quality of health will have an impact on the decline in intellectual quality. As it is known that the performance of the human brain needed to solve a problem requires adequate or ideal nutrition. Malnutrition is the most important factor in the decline in intellectual quality. (4) Low Skills. In principle, skills are a form of creativity. This activity must be supported by adequate health conditions and of course an adequate intellectual quality. People who experience malnutrition or are prone to health problems are relatively difficult to develop their skills. This is because health support to support the development of work creativity is relatively low so that they do not have many opportunities to improve the quality of their skills. (http://e-journal.uajy.ac.id/1756/3/2EP15294.pdf).

In general, the problem of poverty in the village is caused by the limited control of agricultural lands and productive tools. Inequality of ownership of agricultural assets makes farmers as laborers whose income is relatively low. This fact shows that poverty is not only related to the ability to meet material needs, but also to other dimensions. According to Sharp in Mudrajad (1997), he tries to identify the causes of poverty from an economic perspective. First, on a micro level, poverty arises because of the unequal pattern of resource ownership that results in an unequal distribution of income. The poor have only limited resources and low quality. Second, poverty arises from differences in the quality of human resources. Low quality of human resources means low productivity, which in turn lower wages. The low quality of human resources is due to low education, unfortunate fate, discrimination or heredity. Third, poverty arises from differences in access to capital. Meanwhile, according to Sumodiningrat (1998), poverty consists of: (1) cultural poverty, (2) natural poverty, and (3) structural poverty. Cultural poverty is a condition of poverty that occurs because from the beginning it is poor These community groups become poor because they do not have adequate resources, either natural resources, human resources or development resources, or if they participate in development, they only get low income rewards. Natural poverty is poverty caused by natural factors such as disability, illness, old age or natural disasters. Areas like this are generally areas that are critical of natural resources or isolated areas. Cultural poverty is a condition of poverty that occurs because of the culture, culture or customs adopted by a community group. Cultural poverty refers to the attitude of life of a person or group of people caused by lifestyle, living habits and culture in which they feel that they live in abundance and do not feel deprived. Community groups like this are not easy to invite to participate in development, do not want to try to improve and change their level of life. As a result, their income level is low according to the standard used. The cause of poverty is due to cultural factors such as laziness, undisciplined, wasteful and others. Structural poverty is poverty caused by manmade factors such as unfair economic policies, unequal distribution of production assets, corruption and collusion and the world economic order that tends to benefit certain groups of people. The emergence of structural poverty is caused by trying to overcome natural poverty, namely by planning various programs and policies. However, due to unbalanced implementation, unequal ownership of resources, unequal opportunities cause community participation to become unequal, resulting in an unequal community structure. The inability or helplessness to participate in various aspects of the economy, social, culture and politics makes the community limited to its involvement in the development process. According to Pasandaran (1994), poverty is a profile of people's lives that describe their inability to live properly and participate in ongoing and ongoing development. This poverty will hinder their development, make it difficult for the community at large, by itself hinder development. The low quality of the economic activities carried out will result in the lack of being able to meet their needs. Poverty also results in low community participation in development, due to the lack of capabilities so that people lack the confidence to be involved in the development process. This usually creates a gap between development goals and the hopes and desires of the lower class. To that end, Chamber (1987) argues that poverty is an integrated concept that has six dimensions, namely: (1) Poverty (Proper). The problem of poverty, as in its initial view, is a condition of the inability of income to meet basic needs. This concept or viewpoint applies not only to groups that do not have income, but also to groups that already have income. (2) Powerless. In general, low income capacity will have an impact on the social power of a person or group of people, especially in obtaining justice or equal rights to obtain a decent living for humanity. (3) Vulnerability in facing emergency situations (State of emergency). (4) A person or group of people who are called poor does not have or the ability to face unexpected situations where this situation requires an allocation of income to solve it. For example, vulnerable situations in the form of natural disasters, health conditions that require relatively high medical costs, and other emergency situations that require sufficient income capacity. Conditions in poverty are considered incapable of dealing with this situation. (5) Dependency (dependency). The limited income capacity or social strength of a person or group of people who are called poor causes a very high level of dependence on other 
parties. They do not have the ability or power to create solutions or solve problems especially those related to the creation of new income. Assistance from other parties is needed to overcome problems, especially those related to the need for sources of income. (6) Isolation. The dimension of alienation as meant by Chambers is the location factor that causes a person or group of people to be poor. In general, these so-called poor people are located in areas far from the centers of economic growth. This is because most of the welfare facilities are concentrated in centers of economic growth such as in urban areas or big cities. People who live in remote areas or are difficult to reach by welfare facilities have a relatively low standard of living so this condition is the cause of poverty (http://e-journal.uajy.ac.id/1756/3/2EP15294.pdf).

From some of the thoughts above, that the problem of poverty is related to the low level of community income with various dimensions and factors that cause it. For this reason, the strategy to cut social poverty is to increase people's income. Many community empowerment strategies have become the government's choice and concern, and one of them is through the one village one product or one village one product movement. The concept of One Village One Product (OVOP) as a social movement to generate rural economic vitality, as a result of the large number of villagers who urbanize into cities. The OVOP movement is intended as an effort to revive the village economy through a progressive movement to improve and improve the quality of village business products that are possible to have the uniqueness of the products produced. The OVOP movement was not carried out in large portions but was a program developed on a small scale with limited capital and resources. Communities develop their villages through the development of more competitive local business products and have the opportunity to reach modern markets. For this reason, synergy between the government and the community is needed to determine village business products that have advantages to be used as village superior products. Community involvement is intended as an effort to support citizens because it is a major factor in the success of OVOP.

The OVOP approach can be interpreted as a strategy in building superior products from each village that are unique, unique, and have great opportunities to enter modern markets. This uniqueness can be in the form of products for the development of cultural culture, arts, and / or forms / raw materials of the products produced. Because of its uniqueness, it becomes an attraction for the wider community to get to know and buy these products, so that it can encourage increased productivity and the income of villagers. Meanwhile, the OVOP movement as an institutional forum cannot be separated from the values it adheres to as the basis for its various activities. These values are conceptualized in the form of the basic principles of the movement, according to the International Exchange Promotion Committee, there are three principles in OVOP: First, Think Globally, Act Locally where local communities are expected to be able to create products of local pride that have a global reputation; Second, Self Reliance and Creativity, the main driving force behind the OVOP movement is the community itself. Mobilizing the role of society with creativity, innovation, persistence, and potential resources. Public knowledge is one of the basic principles of the OVOP movement. The community determines the selected product that has real specialties/uniqueness. Third, Human Resource Development. The development of local community human resources is a very important principle in the OVOP movement. People must have high motivation to transform challenges into opportunities, never give up in their search, never suffer from failure, but continuously strive to face change (Titik Yuliani, 2012). Meanwhile, the community considers that local products do not have universal characteristics that can attract the attention of the wider community and even the international community. In terms of local products developing based on the development of local cultural potential that has certain characteristics that are not found in other regions, so that it becomes a special attraction for the global community. The only thing that needs to be considered is the quality of the products produced by local communities in order to have high product competitiveness to enter modern markets. In addition, to ensure marketing continuity, it is necessary to increase the ability of local business actors through intensive training to foster creativity and product innovation in accordance with the demands of market developments. The success that is expected through the OVOP program can increase the income of villagers and welfare for the community, especially village business actors. However, success in implementing the OVOP concept cannot be separated from the participation and cooperation of three elements known as the Triple Helix, namely: government, entrepreneurs, and intellectuals. The cooperation is intended to provide support for the development of local business products in order to exist and be able to increase the competitiveness of local products in local, regional, national and international markets. In addition, the role of this collaboration aims to encourage innovation, as well as foster a spirit of togetherness and continue to develop skills in improving product quality in order to be able to compete.

From the above thought, it can be stated as a hypothesis in this study, are:

1. Ho $=$ There is no influence of the One Village One Product (OVOP) Approach on the handling of Social Poverty,

2. $\mathrm{Ha}=$ There is an effect of the One Village One Product (OVOP) Approach on the handling of Social Poverty. 
While the focus and direction of this research can be described in the following diagram:

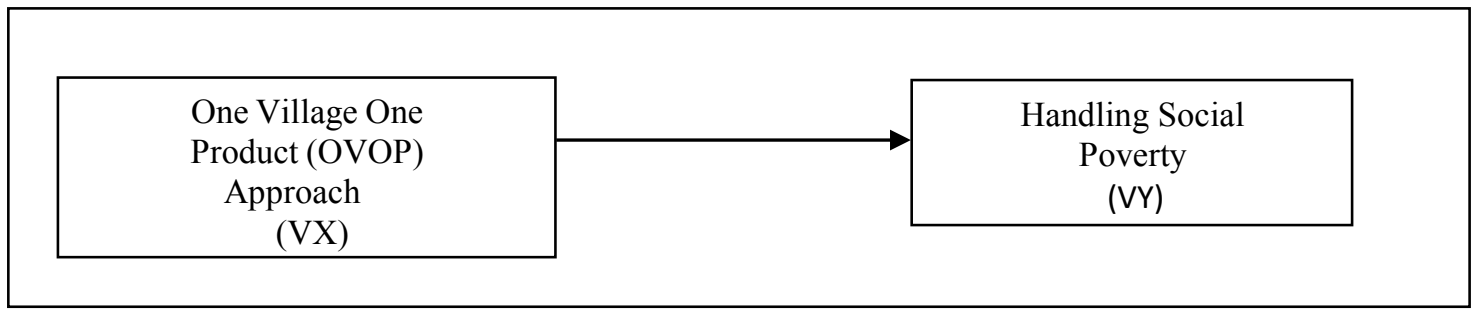

\section{RESEARCH METHODS}

This study uses a quantitative approach to determine the effect of the One Village One Product (OVOP) approach on Social Poverty Management. Data were collected by distributing questionnaires to 120 randomly selected respondents in 6 villages in Ngawi Regency. Each village was assigned 20 respondents using stratified random sampling, consisting of: village heads and village officials, BPD, LKMD, PKK, and village community UMKM-UMKM. The respondent's assessment is measured using a Likert scale with a gradation from very positive to very negative, in the form of words including: a) Strongly agree with a score of 5, b) agree with a score of $4, \mathrm{c}$ ) Doubtful with a score of 3, d) No agree with a score of 2, and e) Strongly disagree with a score of 1. While the data analysis method uses a regression analysis model with processing through SPSS.

\section{RESULTS AND DISCUSSION.}

Regression Test

The results of the regression calculations between the variables of the OVOP Approach to the handling of Social Poverty are:

Table. 1 Coefficients

Effect of One Village One Product (OVOP) Approach on Handling Social Poverty

\begin{tabular}{|c|c|c|c|c|c|c|}
\hline \multirow[b]{2}{*}{ Model } & & \multicolumn{2}{|c|}{ Unstandardized Coefficients } & \multirow{2}{*}{$\begin{array}{c}\text { Standardized } \\
\text { Coefficients } \\
\text { Beta } \\
\end{array}$} & \multirow[b]{2}{*}{$\mathrm{t}$} & \multirow[b]{2}{*}{ Sig. } \\
\hline & & B & Std. Error & & & \\
\hline 1 & (Constant) & -.493 & 1.502 & & -.328 & .743 \\
\hline & $\begin{array}{l}\text { OVOP } \\
\text { Approach }\end{array}$ & 1.009 & .027 & .959 & 36.893 & .000 \\
\hline
\end{tabular}

a. Dependent Variable: Handling Social Poverty

From the regression equation ( $\mathrm{Y}=\mathrm{a}+\mathrm{bX}$ ), it can be identified: (1) The constant value is -0.493 ; shows the One Village One Product (OVOP) approach will be constant if the variable for handling Social Poverty is equal to zero (none), assuming other factors remain or do not change in value. (2)

The one Village One Product (OVOP) approach variable which is valued at 1.009 (positive) indicates the influence of the One Village One Product (OVOP) Approach on the handling of Social Poverty. If the one Village One Product (OVOP) approach increases by 1 unit, the handling of social poverty also increases by 1.009. Thus, the One Village One Product (OVOP) approach has a positive effect on the handling of social poverty.

F test.

To identify the significant effect of the OVOP approach on handling social poverty, it can be done through the F test. The results of the calculation show:

Table. 2

Test F: Effect of One Village One Product (OVOP) Approach on Handling Social Poverty

\begin{tabular}{llc|c|c|c|c}
\multicolumn{2}{c}{} & \multicolumn{5}{c}{ ANOVA $^{\mathbf{a}}$} \\
Model & & Sum of Squares & df & Mean Square & F & Sig. \\
\hline \multirow{2}{*}{1} & Regression & 7743.926 & 1 & 7743.926 & 1361.064 & $.000^{\mathrm{b}}$ \\
\cline { 2 - 7 } & Residual & 671.374 & 118 & 5.690 & & \\
\cline { 2 - 7 } & Total & 8415.300 & 119 & & & \\
\hline
\end{tabular}

a. Dependent Variable: Handling Social Poverty

b. Predictors: (Constant), OVOP Approach

From the results of the $\mathrm{F}$ test, it can be seen that the calculated $\mathrm{F}$ value is $1361,064>\mathrm{F}$ table is 1.368 at the $95 \%$ confidence level. Thus, it can be seen that the OVOP variable simultaneously affects the Social Poverty Management variable significantly or significantly. 
Determination Test.

The coefficient of determination (R2) is used to measure how far the model's ability to explain the variation of the dependent variable. The results of the determination coefficient test are:

Table 3

Results of the Determination Test between the One Village One Product (OVOP) Approach and handling of Social Poverty

\begin{tabular}{|c|c|c|c|c|}
\hline \multicolumn{5}{|c|}{ Model Summaryb } \\
\hline Model & $\mathrm{R}$ & $\begin{array}{c}\mathrm{R} \\
\text { Square }\end{array}$ & $\begin{array}{l}\text { Adjusted R } \\
\text { Square }\end{array}$ & $\begin{array}{l}\text { Std. Error of the } \\
\text { Estimate }\end{array}$ \\
\hline 1 & $.959^{a}$ & .920 & .920 & 2.38529 \\
\hline
\end{tabular}

a. Predictors: (Constant), OVOP Approach

b. Dependent Variable: Handling Social Poverty

The magnitude of the Multiple Coefficient of Determination (R Square) is 0.920 or $92.2 \%$, which means that the handling of social poverty can be explained by the one Village One Product (OVOP) approach variable, while the remaining $07.8 \%$ is explained by other variables not explained in this study. . The OVOP approach is one of the potential alternatives to address poverty in rural areas. Many business actors are run by villagers, but the business activities carried out are still classified as traditional and have limited resources to support them. If the business that has been occupied by the community members receives attention and guidance from the central, regional and village governments, it can become a source of economic potential for community members, so as to break the chain of poverty in the village. The government's attention to citizen business actors can be in the form of: First, providing assistance facilities, both capital and business equipment needed. Limited working capital and lack of business equipment make the quality and quantity low. Second, provide guidance and training for village business actors so that they can be more focused and innovative in developing their business products in accordance with their development. Third, providing training and strengthening village business institutions so that they can be managed more effectively through good business management. Fourth, provide space and opportunity for business actors to promote their products in certain events initiated by local governments. With the development of village business products, it will increase the income and welfare of villagers.

\section{CONCLUSION.}

The OVOP approach is a strategy in dealing with social poverty, through community empowerment, in particular developing the business sector of villagers. Through the OVOP approach, it is able to initiate the business activities of the villagers into superior village products that have high enough competitiveness to fill local, regional, and national markets, so as to increase village residents' income and welfare. Strategic steps in the implementation of OVOP, namely: (1) Conducting a selection of community business products that are designated as superior village products, with the consideration that most of the residents become business actors and the selected products have characteristics that are not owned by other village products. (2) The establishment of village business institutions in the form of MSMEs which become the forum for the activities of village business actors. (3) The commitment of the local/village government to provide guidance and training in the development of business products in order to have quality so that the competitive power is high enough to enter modern markets. (4) Local governments facilitate business capital assistance and transfer of technology equipment to support productivity.

\section{CONFLICT OF INTEREST}

There is no conflict of interest.

\section{ACKNOWLEDGMENTS}

This article is sponsored by the Kemenristik-Dikti Indonesian Research Grants Program.

\section{REFERENCES}

Andika Drajat Murdani, 2018, Pembangunan Ekonomi Pedesaan: Konsep, Prinsip, Strategi, hingga Implementasi Dana Desa, https://www.portal- ilmu.com/2018/03/ pembangunan-ekonomi-pedesaankonsep_19.html

DISKOPUKM-OVOP Indonesia, https://koperasi.kulonprogokab.go.id/detil/147/ovop-indonesia

Gany A R. 2001. Demokratisasi Masyarakat Desa Dinamika Politik dan Kelembagaan Politik Desa. Jurnal Pengembangan Partisipasi Masyarakat Vol. 9 No. 22 Juni 2001.

Hutagalung, 1964, Masalah Pembentukan Modal di Negara - negara Yang Sedang Membangun, Jakarta, Bhratara.

Kartasamita, Ginandjar. 1996. Pembangunan Untuk Rakyat; Memadukan Pertumbuhan dan Pemerataan. Jakarta. CIDES. 
Mudrajad Kuncoro, 1997, Ekonomi Pembangunan, Yogyakarta, UPP AMP YKPN Nugroho, Heru. 1995. Kemiskinan, Ketimpangan dan Kesenjangan. Yogyakarta : Aditya Media.

Pasandaran, E. 1994. Hasil penelitian upaya penanggulangan kemiskinan di Nusa tenggaraTimur Kabupaten Ende dan Timor Tengah Utara. Jakarta: Puslitbangnak.

RN Adriani, 2017, MPLEMENTASI PROGRAM ONE VILLAGE ONE PRODUCT...media.neliti.com , publications > 209212-none

Sumodiningrat, Gunawan, 1997, Pembangunan Daerah dan Pemberdayaan Masyarakat, Jakarta, PT. Bina Rena Pariwara.

1998, Membangun Perekonomian

Rakyat, Yogyakarta, Pustaka Pelajar.

Titik Yuliani, 2012, Analisis Aspek Kelembagaan Koperasi dalam Melaksanakan Program ONE VILLAGE ONE PRODUCT (OVOP) Binaan Kementerian Koperasi Dan Usaha Kecil Menengah (Studi Koperasi Mitra Tani Parahyangan, Kabupaten Cianjur, Jawa Barat ), Skripsi, lib.ui.ac.id/file?file=digital/20318059-STitik\%20Yuliani.pdf

Wijayanti, D, 2005, EKONOMI PEMBANGUNAN ANALISIS ... - Journal UII, journal.uii.ac.id > JEP , article , download.

21 BAB II LANDASAN TEORI 2.1. Kemiskinan 2.1.1. Pengertian ..., http://ejournal.uajy.ac.id/1756/3/2EP15294.pdf

PENgUKURAN gARIS KEmISKINAN dI INdoNESIA $\quad \ldots \quad-\quad \ldots, \quad$ http://www.tnp2k.go.id/ download/79169WP480304FINAL.pdf

Strategi Penanggulangan Kemiskinan Di Indonesia; http://www.braindilogsociology.or.id/2017/12/strategi- penanggulangan-kemiskinan-di.html 